\title{
Molecular Characterization of Virulence Factors and Microbial Resistance of Different Bacterial Isolates in some Dairy Products
}

\author{
Waleed K. Alkhafaje \\ faculty of science \\ Safaa Mohamed Ali ( $\nabla$ safaa.mohamedali@yahoo.com) \\ City of Scientific Research and Technological Applications Genetic Engineering and Biotechnology Research Institute \\ https://orcid.org/0000-0001-9850-0174 \\ Zakia A. Olama \\ faculty of science, Alexandria university
}

\section{Research article}

Keywords: resistance, gene, cheese, bacteria, dairy products

Posted Date: February 25th, 2020

DOI: https://doi.org/10.21203/rs.2.24496/v1

License: @) (1) This work is licensed under a Creative Commons Attribution 4.0 International License. Read Full License 


\section{Abstract}

Background: Bacterial contamination of milk and dairy products is a common problem. Foodborne microbial diseases reason for 20 million cases annually in the world. In the last two years, foodborne diseases caused by the intake of dairy products have been mostly disturbed with Salmonella entertica, Listeria monocytogenes Escherichia coli 0157:H7 and Campylobacter jejune. Aim of the study is to isolate MDR bacteria in dairy product and study of molecular characterization of that isolates.

Results: A total 30 out of 131 bacterial isolates were MDR and distributed as $50 \%$ from white cheese, $36.7 \%$ from industrial white cheese, 13.3 from old cheese and $6.6 \%$ roomy cheese. The incidence of MDR bacterial isolates revealed the abundance of Staphylococcus sp. with $43.3 \%$ among all the tested bacterial isolates, while the other tested isolates showed Bacillus sp $16.7 \%$, Salmonella 13.3\%, E.coli $10 \%$, Enterococcus $6.7 \%$ Psedoumonas $3.3 \%$, Shegella $3.3 \%$ and Proteous $3.3 \%$. Molecular studies of genes presence or absence for class A (TEM, CTX and BSHV), class B (VIM, IMP, KPC and NDM), class C (FOX) and class D (OXA-10, OXA-24 and OXA-58) were tested. NDM, TEM, CITM and (OXA -10) genes were the most abundant the selected bacterial isolates.

Conclusions: The results of this study indicate that cheese made from unpasteurized milk can pose a significant risk to consumers. Product manufacturing processes should be subject to health control-to-control pathogens. Reducing the surface area exposed to air reduces harmful microbial growth in dairy products.

\section{Background}

Spoiling milk products worldwide is a huge economic problem. The microbial capacity and incidence of the bacterial pathogens in foods are indicators of food quality. In addition, the education of food handlers about personal hygiene is importance from food safety point of view [1]. The highly nutritious nature of dairy products makes them especially good media for the growth of microorganisms [2]. The microbial contamination is one of the leading causes of food spoilage worldwide [3]. The contamination of food with microbes can occur at any stage of the foodchain[4].A large number of diseases are caused by foodborne pathogens with significant effects on economy and human health.Bacterial pathogens use a variety of different motility modes, including swimming, twitching, and swarming [1]. S.aureus is commonly food born pathogen of great importance of animal and human concern. it is responsible for contaminate dairy products, kariesh cheese and ice cream from different sources during their production, processing and handling that make them unfit for human consumption or even a dangerous source of infection among customers establishing a potential health hazard [5]. S. aureus is also known for its ability to secrete a host of toxins to aid in host tissue infiltration and acquire nutrients [6]. The features of the most common pathogenic bacteria (Salmonela, Shigella, Listeriamonocytogenes, Bacilluscereus, Campylobacter, Clostridium, Cronobacter, E.coli, Staphylococccus aureus, Vibrio, Yersinia enterocolitica, viruses (Hepatitis A and Noroviruses) and parasites (Cyclospora cayetanensis, Toxoplasma gondii and Trichinella spiralis [7, 8]. Antimicrobial resistance (AMR): the ability of microbes to grow in the presence of a drug that would normally kill them or limit their growth $[9,10]$. AMR complicates infection treatment is linked to increased mortality and morbidity. The emergence and spread of resistant and multidrug-resistant (MDR) bacteria has enormous implications for worldwide healthcare delivery and population health $[11,12,13]$.Virulence functions are often encoded on large extrachromosomal plasmids by pathogenic bacteria. These plasmids are maintained at low copy number to reduce the metabolic burden on their host $[14,15]$. The widespread use of extended-spectrum cephalosporin creates a reservoir of resistant bacteria. Moreover, multi-resistance frequently associated with strains carrying ESBLs, which could dramatically reduce the treatment options. The increasing number of Enterobacteriaceae with ESBLs that also contain MBLs or AmpCs and other new mechanisms of resistance to fluoroquinolones or aminoglycosides indicate that recent increase of ESBLs - producing bacteria in Europe constitutes a complex problem [16]. ESBLs are worthy of the scientific community's attention over the past decades among the $\beta$-lactamases. ESBL's older and classical definition includes TEM-1, TEM-2, or SHV derivatives. ESBL is divided into three main groups by the most recent definition. (I) ESBLA (class A ESBLs): CTX-M, SHV and TEM enzymes. (II) ESBLM (miscellaneous ESBLs) are sectioned into ESBLM-C (class C, plasmid mediated AmpC) and ESBLM-D (class D). (III) ESBLCARBA (ESBLs that degrade carbapenems) are divided into ESBLCARBA-A, ESBLCARBA-B, and ESBLCARBA-D. More than $500 \beta$-lactamases have been reported to date produced by diverse bacteria. Beta-lactamases be the most common resistance mechanism that contributes to widespread resistance among Gram-negative microbes [17]. Transmission of resistance occur between microorganisms [18]. NDM-1 producing E. coli infects the host by commonly invading sites like, urinary tract, blood, lungs, and wounds, leading to urinary tract infections, septicemia, pulmonary infections, diarrhea, peritonitis, device-associated infections and soft tissue infections [19]. 


\section{Methods}

\subsection{Samples}

Dairy products: samples from different locations in Alexandria were collected during 2018: white cheese, white cheese produced, old cheese and milk. The samples were collected for further use in sterile containers.

\subsection{Assessment of isolated bacteria's resistance prevalence}

According to the modified Kirby-Bauer Disc Diffusion method, all the isolated bacteria (130 isolates) were subjected to antibiotic resistance using the disk diffusion method.

\subsection{Microorganisms and molecular identification}

The most promising isolates (antibiotic resistant isolates) were subjected to phenotypic identification using cultural characteristics in a trail to be identified. Gram staining and analysing biochemistry. The region of 16S rRNA was amplified using the universal primers (F: AGAGTTTGATCMTGGCTCAG and R: TACGGYACCTTGTTACGACTT). PCR reaction, was performed for 4 min at $95^{\circ} \mathrm{C}$ followed by 40 cycles each of $\left(40 \mathrm{sec}\right.$ at $94^{\circ} \mathrm{C}, 50 \mathrm{sec}$ at $58^{\circ} \mathrm{C}$ and $50 \mathrm{sec}$ at $72^{\circ} \mathrm{C}$ ), followed by a supplementary $10 \mathrm{~min}$ at $72^{\circ} \mathrm{C}$. Sequences of the $16 \mathrm{~S}$ rRNA genes were obtained from the NCBI database. Multiple alignments based on the most closely related sequences and similarity levels were carried out using the BLAST program1. A phylogenetic tree was reconstructed using the Mega 5 software.

\subsection{Bacterial resistance determination using molecular techniques}

Fresh bacterial cells were used to extract DNA using the GeneJET Genomic DNA Purification Kit. GEBRI kit removed plasmid from the bacteria's selected isolates.

\subsubsection{Virulence gene detection using PCR}

Twenty-one primers were designed; the genus used for screening of ESBL class A were TEM, CTX MUI, CTX BETA and BSHV (Table 1). ESBL class $B$ carbapenemase encoding genus were CITM, VIM, IMP, KPC and NDM. ESBL class $C$ encoding genus was FOX, ACCM. ESBL class D encoding genus was OXA-10, OXA-55, OXA58, OXA 60 and OXA 69. Screening for coding sequence of genes DHAM, and EBCM, MEC A, VAN A, and TOHO1 were evaluated. PCR reaction was achieved for 4 min at $95^{\circ} \mathrm{C}$ followed by 35 cycles each of: $40 \mathrm{sec}$ at $94^{\circ} \mathrm{C}, 50 \mathrm{sec}$ at $(50-60){ }^{\circ} \mathrm{C}$ (according to primer) and $50 \mathrm{sec}$ at $72^{\circ} \mathrm{C}$, followed by a supplementary $10 \mathrm{~min}$ at $72^{\circ} \mathrm{C}$. After amplification by PCR, the products were checked in $2 \%$ agarose gel electrophoresis. Genetic miscellany was determined as the experimental number of differentiation. The primers used throughout the present work illustrated in (table 1).

\section{Results}

\subsection{Sample collection and analysis of microbiology}

To evaluate the incidence of isolates of bacterial ESBL and CR in certain dairy products at various locations in Alexandria, Egypt. A total of 100 samples were collected that were distributed as follows: Kareish cheese, Industrial white cheese, Old cheese, Romy cheese and milk (40, 28, 15, 10 and $7 \%)$ respectively.

\subsection{Assessment of isolated bacteria's resistance prevalence}

All bacterial isolates (130) have been tested with different types of antibiotics for antibiotic resistance.Multiantibiotic resistance was shown by the biggest promising isolates (30). 7bacterial isolates were isolated from milk but show sensitive effect towards the antibiotic used for detection of MDR bacteria. All the selected MDR isolates were resistance to metronidazole (MTZ). Incidence of antibiotic sensitivity of multi-antibiotic resistance bacterial isolates present in table 2. Distribution of the MDR bacterial isolates were 11 isolates from kariesh cheese (out of 52 bacterial isolates), 5 isolates from 
industrial white cheese (out of 19 bacterial isolates), 4 isolates from old cheese (out of 37 bacteria isolates) and 2 isolates from romy cheese (out of 13 bacteria isolates).

\subsection{Identification of the bacterial isolates}

To identify the bacterial selected with the most promising MDR (30 out of 130 isolates). The most commonly isolated pathogens were evaluated for phenotypic characterization and molecular identification using $16 \mathrm{~s}$ rDNA. The amplified fragment sequences of $1500 \mathrm{bp}$ were easily identified. A dominant tool for identifying and classifying prokaryotes was the sequences of the different types of strains from gene bank. GenBank deposited the sequence of the most promising isolates and had the accession. From all the examined samples were staphylococcussp, Bacillus sp, Salmonella sp, E.coli, Enterococcus sp, Pseudomonas sp, Shigella sp and Proteous $s p$. with $43.3,16.7,13.3,10,6.7,3.3,3.3$ and $3.3 \%$ respectively. $23.1 \%$ out of the total isolates (130) were pathogens.

\subsection{Resistance determination using molecular technique}

The variation between the isolated MDR bacteria were shown by plasmid extraction of the selected bacterial isolates. Results in figure (1) showed that isolates $2,9,16,19,20,24,25,27,29,30,39,40$ and 41 were highly antibiotic-resistant positive plasmid with high copy numbers.

\subsubsection{Detection of virulence gene using PCR}

3.4.1.1. Detection of $\beta$-lactamase gene class $A, B, C$ and $D$ in the selected bacterial isolate: Collected data of genes presence or absence for class A (TEM, CTX and BSHV), class B (VIM, IMP, KPC and NDM), class C (FOX) and class D (OXA-10, OXA-24 and OXA58) were tested. The fragment size of amplified PCR product was calculated using software of Gel Documentation Analysis System (Alpha Imager TM 1220). Results in fig (2) showed the average percentage of positive genes in all the selected MDR (30isolates). Distribution of presence or absence of the 20 tested virulence genes among the MDR bacterial isolates ( 30 tested isolates) were illustrated in supplementary file (fig 1 - 19).

\section{Discussion}

Studies previously conducted in different countries revealed a wide $S$. aureus diversity in dairy products. The prevalence of $S$. aureus was $43.3 \%$ and it was differing than which carried out from Iran and Italy on different dairy products revealed a lower $S$. aureus percentage. Lower prevalence noted in studies of $[20,21,22]$ who detected $S$. aureus with $(10 \%, 11.25 \%, 5 \%$ and $9.1 \%$ respectively) of kariesh cheese samples. Greater incidence were informed by $[23,24,25]$ as a result of which $S$. aureus was $72 \%, 50 \%, 70 \%, 93 \%$ and $68 \%$ respectively of kariesh cheese samples.

Percentage of Bacillus sp. in our study was $16.7 \%$ and were isolated from industrial white cheese and kareish cheese where it was higher percentage in industrial white cheese. It was differed than the study by EFSA 2005 where the incidence of B.cereus was highest in karish cheese (25 to $80 \%$ ) during all seasons followed by koshary (45 to $70 \%$ ) and cornsnacks (20 to $50 \%$ ).

Percentage of Salmonella sp. In our study was $13.3 \%$ that were isolated from industrial white cheese and kareish cheese (10\% and $3.3 \%)$. Relatively lower results were obtained by $[26,27,28,29,30,31]$ where salmonella species could not be identified in the surveyed white cheese samples. Ghada et al. (2004) identified two samples polluted with Salmonella sp.

In our study the E.coli percentage was $10 \%$ isolated from romy, kareish and industrial white cheese compared to other bacterial isolates. In study by Abdelrahman et al. (2019) found that the incidence of E.coli in Kariesh, and Domiati cheese were $37.1 \%$ and $2.8 \%$, respectively. While, could not be detect in Tallaga cheese. Najand and Ghanbarpour (2006) who isolated E.coli with percentage of $98.70 \%$ from domestic soft cheese. Paneto et al (2007) isolated $E$. coli with percentage of $96 \%$ from raw milk cheese. Elsayed et al (2011) isolated E.coli with percentage of $40 \%$ from white soft cheese. Bonyadian et al. (2014) isolated $E$. coli with percentage of $48 \%$ from cheese samples. Ombarak et al. (2016) isolated E.coli from with percentage of $76.4 \%$. Amer and Ewina (2003) and Eman (2015) where they isolated E.coli with percentage of $37.5 \%$. While comparatively lower result were obtained by Brooks et al.(2012) as they found that 2 out 41 raw milk cheese samples were contaminated with E.coli.

A common principal of resistance markers in all varieties estimated and associated antimicrobials such as tetracyclines, B-lactams, sulfonamide and quinolones were detected [42].An aggregate number of extended-spectrum $\beta$-lactamases (ESBLs) have been 
predictable in Enterobacteriaceae through the latest few years. SHV types of enzymes have been shown to carry SHV-1 gene within the chromosome [43]. NDM-1 producers were found resistant to imipenem, meropenem, ertapenem, gentamicin, amikacin, tobramycin, and ciprofloxacin, whereas, isolates were found susceptible to colistin [44]. The high prevalence of tetracycline- and penicillin-resistant (S. aureus, Salmonella and E.coli) observed in the current study, is in agreement with earlier findings. TEM are mostly preset by Gram-negative bacteria. Almost $90 \%$ of the resistance against ampicillin in Gram-negative bacteria are due to TEM encoded genes [46].

\section{Conclusions}

The results of this study indicate that cheese made from unpasteurized milk can pose a significant risk to consumers. This risk varies depending on the geographical location of the study area, the state of education of the population, the extent of attention to hygiene and the method of preparing and packaging dairy products.

Product manufacturing processes should be subject to health control-to-control pathogens. Dairy markets should be monitored for pathogens. Reducing the surface area exposed to air reduces harmful microbial growth in dairy products.

\section{Declarations}

Ethics approval and consent to participate: No need for it .

Consent for publication: All authors agree for publication.

Availability of data and material: All data available

Competing interests: No competing

Funding: This work has no fund

\section{Authors' contributions:}

WKA: Sample collection, screening of MDR bacteria and gene detection.

SMA: proposed the work, help student (Waleed ) in the experimental part, funded fine chemical, wrote the manuscript and analyzed the experimental data

ZAO: supervised and revised the manuscript.

\section{All authors agree for publication that work in BMC microbiology.}

Acknowledgements: Not Applicable

\section{Abbreviations}

Multidrug-resistant: (MDR), Antimicrobial resistance: (AMR), Metallobetalactamases: (MBLs), AmpC: Enzymes encoded by resident chromosomal genes (cAmpCs) are produced by some species, Extended-Spectrum Beta-Lactamase: (ESBL).

\section{References}

1. Mahendra, P., Selamawit, M., Muluken, T., Suneeta, V. P., Prajapati, J. P., 2016. Bacterial Contamination of Dairy Products. Beverage and food world. 43:40-43.

2. Pal, M., Bekele, T., Feleke, A., 2012. Public health significance of pasteurized milk. Beverage and Food World. 39: 55-56.

3. Pal, M., 2014. Spoilage of dairy products due to fungi. Beverage and Food World. 41:37-38.

4. Vrdoljak, J., Dobrani, V., Filipovi, I., Zdolec, N., 2016. Microbiological quality of soft, semi-hard and hard cheeses during the shelflife. Journal of Macedonian Veterinary Review. 39:59-64. doi: 10.1515/macvetrev-2015-0068. 
5. El-Malt, L.M., Hameed, K.G.A., Mohammed, A.S., 2013. Microbiological evaluation of yoghurt products in Qena city, Egypt. Veterinary World, 6: 400-404. doi:10.5455/vetworld.2013.400-404.

6. Kong, C., Neoh, H., Nathan, S., 2016. Targeting Staphylococcus aureus Toxins: A Potential form of Anti-Virulence Therapy. Toxins;8:72. doi: 10.3390/toxins8030072.

7. Bintsis, T., 2017. Foodborne pathogens. AIMS microbiology. 3.3: 529.

8. Suvra, D., G.M.M., Anwarul, H., Sahana, P., 2015. Evaluation of Microbial Load And Quality of Milk \& Milk Based Dairy Products. Octa Journal of Biosciences. sciencebeingjournal.com/sites/default/files/1\%20Evaluation\%20of\%20Microbial\%20Load\%20And\%20Quality\%20of\%20Milk_0.

9. World Health Organization. Antimicrobial Resistance: Global Report on Surveillance. Switzerland: World Health Organization, 2014.https://www.who.int/drugresistance/documents/surveillancereport/en/

10. World Health Organization. Antimicrobial resistance 2015.

11. Alison, H. H., Arnfinn, S., Luke, S.P.M.,Martin, S., 2015. Understanding the mechanisms and drivers of antimicrobial resistance, lancet. dx.doi.org/10.1016/S0140-6736(15)00474-2.

12. Holmes, A.H., Moore, L.S.P., Sundsfjord, A., Steinbakk, M., Regmi, S., Karkey, A., Guerin, P.J., Piddock, L.J.V., 2015. Understanding the mechanisms and drivers of antimicrobial resistance. The Lancet. 387: 176-187.doi: 10.1016/S0140-6736(15)00473-0.

13. Liu, Y.Y., Wang, Y., Walsh, T.R., Yi, L.X., Zhang, R., Spencer, J., Doi, Y., Tian, G., Dong, B., Huang, X., 2016. Emergence of plasmidmediated colistin resistance mechanism MCR-1 in animals and human beings in China: a microbiological and molecular biological study. The Lancet Infectious Diseases. 16: 161-168.doi: 10.1016/S1473-3099(15)00424-7.

14. Davis, G.S., Sevdalis, N., Drumright, L.N., 2014. Spatial and temporal analyses to investigate infectious disease transmission within healthcare settings. J Hosp Infect. 86: 227-43. doi: 10.1016/j.jhin.2014.01.010.

15. Donker, T., Wallinga, J., Slack, R., Grundmann, H., 2012. Hospital networks and the dispersal of hospital-acquired pathogens by patient transfer. PLoS One. 7: e35002.doi.org/10.1371/journal.pone.0035002.

16. Urumova, V., 2015. Extended spectrum beta lactamase producing animal enterobacteriaceae isolates as potential risk to public health - review, valentina. 166: 192-207.https://www.revmedvet.com/2015/RMV166_192_207.

17. Bush, K., Jacoby, G.A., 2010. Updated functional classification of $\beta$-lactamases. Antimicrobial Agents and Chemotherapy. 54: 969-976.doi: 10.1128/AAC.01009-09.

18. Walsh, T.R., Weeks, J., Livermore, D.M., Toleman, M.A., 2011. Dissemination of NDM-1 positive bacteria in the New Delhi environment and its implications for human health: an environmental point prevalence study. Lancet Infect Dis; 11: 355-62.doi: 10.1016/S1473-3099(11)70059-7.

19. Hu, H., Hu, Y., Pan, Y., Liang, H., Wang, H., Wang, X., Hao, Q., Yang, X., Yang, X., Xiao, X., 2012. Novel plasmid and its variant harboring both a bla(NDM-1) gene and type IV secretion system in clinical isolates of Acinetobacter Iwoffii. Antimicrob Agents Chemother.56:1698-1702. doi: 10.1128/AAC.06199-11.

20. Ahmed, H.F., Aman, I.M., Mohamed A.M., 2004. Bacteriological quality of kareish cheese and atrial to control Staphylococcus aureus in cheese. Alex. J. Vet. 21(2): 514:523.

21. Awad allah M.A.I., 2004. Studies on proteolytic bacteria in milk and cheese in Zagazig markets. M.V.Sc. Thesis Fac. Vet. Med. Zagazig Univ. Egypt.http://www.publications.zu.edu.eg/Pages/PubShow.aspx?ID=26728\&\&pubID=19.

22. El-Shater, N.S., 2010. Evaluation of immunological and bacteriological patterns of some food poisoning microorganisms (Staphylococcus aureus and Clostridium perfringens). Ph.D. Thesis Fact. of Vet. Med. Zagazig University.

23. Kolta, M.N., 2011. Characterization of Staphylococcus aureus superantigens in milk and some dairy products. Ph. D. Thesis. Fac. Vet. Med. Assiut Univ. Egypt.

24. Rania, M.K., Bayoumi. A., Mohamed, A.F.A.S., 2013. MRSA detection in raw milk, some dairy products and hands of dairy workers in Egypt, a mini-survey. Food Control 33: 49-53.

25. Salama, E.M., Saad, A.H., Enan, G.A., Suzan, I.Y., 2015. Incidence and Biocontrol of Staphylococcus aureus in some Milk Products. 2nd Conference of Food Safety, Suez Canal University, Faculty of Veterinary Medicine. .l: 29:35.

26. Sharaf, S.O., Basem, F.D., Ala,Q., Saeid, A., Azmi, D.H., Saleem, A., 2011. The incidence of Listeria species and other indicator bacteria in some traditional foods sold in Karak city. Jordan J. food, Agric. and Environ. 9: 2. 
27. Brooks, J.C., Martinez, B., Stratton, J., Bianchini, A., Krokstrom, R., Hutkins, R., 2012. Survey of raw milk cheeses for microbiological quality and prevalence of foodborne pathogens. Food Microbial. 31: 154-

158.doi.org/10.1016/j.fm.2012.03.013.

28. Akbarmehr, J., Khandaghi, J., 2012. A survey on the prevalence of Salmonella and Coliforms in unpasteurized Iranian cheese using conventional culture method. African. J. Microbiol Res.6: 968-971. doi: 10.5897/AJMR11.987.

29. Hegazy, M.I., Mahgoub, S.A., 2013. Microbiological characterization of the Egyptian soft white cheese and identification of its dominant yeasts. African J. Microbi. Res.7: 2205-2212. doi: 10.5897/AJMR2013.5368.

30. El-Gamal, M.S., El Dairouty, R.K., Okda, A.Y., Sahar, H.S., El-Shamy, S.M., 2013.Incidence and interrelation of Cronobacter sakazakii and other foodborne bacteria in some milk products and infant formula milks in Cairo and Giza Area. World Applied Sci. J. 26: 1129-1141. doi: 10.5829/idosi.wasj.2013.26.09.13542.

31. Abo Zeed, B.A., 2014. Prevalence of Biological Hazards in Milk and Some Dairy products in Egyptian Markets. Ph.D. thesis. Faculty of veterinary medicine, Cairo Univ.http://db4.eulc.edu.eg/eulc_v5/Libraries/Thesis/BrowseThesisPages.aspx? $\mathrm{fn}=$ PublicDrawThesis\&BibID=11822154.

32. EFSA, 2005. Opinion of the scientific panel on biological hazards on Bacillus cereus and other Bacillus spp. in foodstuffs. EFSA J., 175: 1-48. doi:10.2903/j.efsa.2005.175.

33. Ghada, Z.A.A., Alia, M.H., Soha, Al-S., Magdy, N.A., Mohammed, F.S., 2004. Chemical, nutritional and microbiological evaluation of some Egyptian soft cheeses. The Egyptian J. Hospital Med.17: 44-57.http://egyptianjournal.xyz/17_4.pdf.

34. Abdelrahman, M., El Bagoury, Heba, H.S., Hadeer, S., 2019. Incidence of Escherichia coli and Salmonella Species with Special Reference to Antibiotic Resistant Pathogenic E. coli Isolated From Locally Produced Cheeses in Egypt, Alexandria Journal of Veterinary Sciences.doi: 10.5455/ajvs.21944.

35. Najand, L.M., Ghanbarpour, R., 2006. A study on enteropathogenic Escherichia coli isolated from domestic Iranian soft cheese. Veterinarski Arhiv., 76:531-536.

36. Paneto, B.R., Schocken-Iturrino, R.P., Macedo, C., Santo, E., Marin, J.M., 2007. Occurence of toxigenic Escherichia coli in raw milk cheese in Brazil. Arq. Bras. Med. Vet. Zootec., 59: 508-512.

37. El Sayed, M.A., Hosny, I.M., El Kholy, W.I., El Dairouty, R.K., Sahar, H.S.M., 2011: Microbiological evaluation of Egyptian white soft cheeses style. J. Am. Sci. 7: 517- 526.

38. Bonyadian,M., Moshtaghi, H., Mariam, A.T., 2014. Molecular characterization and antibiotic resistance of enterotoxigenic and entero-aggregative Escherichia coli isolated from raw milk and unpasteurized cheeses, Vet. Res. Forum. 5: 2934.https://www.ncbi.nlm.nih.gov/pmc/articles/PMC4279659/

39. Ombarak, R.A., Hinenoya, A., Awasthi, S.P., Iquchi, A., Shima, A., Elbagory, A.R., Yamasaki, S., 2016. Prevalence and pathogenic potential of Escherichia coli isolates from raw milk and raw milk cheese in Egypt Int. J. 16: 221:69-76.

40. Amer, A.A., Ewina, M.A. 2003. Microbial profile of street vended Kareish cheese, Kafr El-Sheikh Vet. Med. J. 1: 837-848.

41. Eman, K.M.F., 2015. Impact of some probiotics on growth of food borne pathogens isolated from milk and soft cheese. Thesis of Fac. of Vet. Med. for M.V.Sci.

42. Fontes, C.O., Silva, V.L., de Paiva, M.R.B., Garcia, R.A., Resende, J.A., Ferreira-Machado, A.B., Diniz, C.G., 2013. Prevalence, antimicrobial resistance, and virulence characteristics of mecA-encoding coagulase-negative Staphylococci isolated from soft cheese in Brazil. J. Food Sci. 78: 594-599.doi: 10.1111/1750-3841.12088.

43. Zhao, W.H., Hu, Z.Q., 2013. Epidemiology and genetics of CTX-M extended-spectrum $\beta$-lactamases in Gram-negative bacteria. Critical Reviews in Microbiology. 39: 79-101.doi: 10.3109/1040841X.2012.691460.

44. Kumarasamy, K.K., Toleman, M.A., Walsh, T.R., Bagaria, J., Butt, F., Balakrishnan, R., 2010. Emergence of a new antibiotic resistance mechanism in India, Pakistan, and the UK: a molecular, biological, and epidemiological study. Lancet Infect Dis. 10:597-602. doi: 10.1016/S1473-3099(10)70143-2.

45. Jamali, H., Radmehr, B., Ismail, S., 2014. Prevalence and antibiotic resistance of Staphylococcus aureus isolated from bovine clinical mastitis. Journal of dairy science. 97: 2226-2230. doi: 10.3168/jds.2013-7509.

46. Sadeeq, R., Tariq, A., ljaz, A., Nazir, A.K., Bo, H.,Jian, Gao., 2018. The Growing Genetic and Functional Diversity of ExtendedSpectrum Beta-Lactamases. BioMed Research International. Article ID 9519718. 
47. Nor Zanariah, Z., Anita, S., Hanafiah, A., Najihan, A.S.,2015. Molecular detection of the New Delhi metallo-b-lactamase-1 genein Enterobacteriaceae isolates in a tertiary medical centre. Malaysian J Pathol. 37(3): 227 - 232.

file:///C:/Users/LENOVO/Downloads/P020160315412241606025.pdf.

48. Patrice, N., Thierry, N.,Laurent, P., 2011.Global Spread of Carbapenemase-producing Enterobacteriaceae. Emerg Infect Dis.17(10): 1791-1798.doi: 10.3201/eid1710.110655.

49. Jyoti, S., Meera, S., Pallab, R.,2010. Detection of TEM \& SHV genes in Escherichia coli \&Klebsiella pneumoniae isolates in a tertiary care hospital from India.Indian J Med Res. 132:332-336.https://www.ncbi.nlm.nih.gov/pubmed/20847381.

50. Hosseini, S., Maleki, A., Ghafourian, S., Reza, M., Fadavi, H. V., Shahmir, P., Sadeghifard, N., 2014. Molecular Characterization of AmpC $\beta$-Lactamases among Klebsiella pneumoniae Isolated from Ilam and Tehran Hospitals, from Iran. Journal of Pure and Applied Microbiology. 8(3): 2217-2220.

51. Taweeporn, S., Chariya, C., Kunyaluk, C., Temduang, L., Chaisiri, W., 2002. Evaluation of different primers for detecting Meca gene by PCR in comparison with phenotypic Methods for discrimination of Methicillin-resistant staphylococcus aureus. Southeast asian j trop med public health. http://www.thaiscience.info/Journals/Article/TMPH/10584463.pdf

52. Khorsi, K., Messai, Y., Hamidi, M., Ammari, H., Bakour, R., 2015. High prevalence of multidrug-resistance in Acinetobacter baumannii and dissemination of carbapenemase-encoding genes blaOXA-23-like, blaOXA-24-like and blaNDM-1 in Algiers hospitals." Asian Pacific journal of tropical medicine. 8.6: 438-446.doi: 10.1016/j.apjtm.

53. Sana, J., Mohd, S., Sobia, F., Anuradha, S., Haris, M.K., 2015. Molecular characterization of genes encoding AmpC betalactamases in clinical isolates of Pseudomonas and Acinetobacter species Journal of Applied Pharmaceutical Science. 5 (10): 048-051. doi: 10.7324/JAPS.2015.501009.

54. Mohammad, S. N., Sreedevi, B., Chaitanya, R. K., Sreenivasulu, D., 2017. Beta-lactamase antimicrobial resistance in Klebsiella and Enterobacter species isolated from healthy and diarrheic dogs in Andhra Pradesh, India. Veterinary World, EISSN: 22310916.www.veterinaryworld.org/Vol.10/August-/20.pdf.

55. Kolar, M., Bardon, J., Chroma, M., Hricova, K., Stosova, T., Sauer, P., \& Koukalova, D. 2010. ESBL and AmpC beta-lactamaseproducing Enterobacteriaceae in poultry in the Czech Republic. Veterinární medicine. 55(3): 119124.https://www.agriculturejournals.cz/publicFiles/165_2009-VETMED.pdf.

56. Frédéric, B., Catherine, B., Nicole L.Z., 2002. Identification of PSE and OXA ß-lactamase genes in Pseudomonasaeruginosa using PCR-restriction fragment length polymorphism. The British Society forAntimicrobial Chemotherapy. 50: 11-18. doi: $10.1093 / \mathrm{jac} / \mathrm{dkf069}$

57. José, A. D., Alejandra, B., Juan, A., Cynthia, R., Ángela, F., Gabriel, O. G.,2014. B-lactamases produced by amoxicillin-clavulanateresistant enterobacteria isolated in Buenos Aires, Argentina: Anew blaTEM gene. Rev Argent Microbiol.46(3):210-217.

58. Patrik, M., Magdalena, R., Milan, K., 2016. Research Article Primer Evaluation for PCR and its Application for Detection of Carbapenemases in Enterobacteriaceae Jundishapur. J Microbiol. 9(1): e29314. doi: 10.5812/jjm.29314.

59. Chih-Chauan, K., Meei-Fang, L., Chin-Fu, L., Yi-Ching, H., Po-Yu, L., Ching-Wen, C., Zhi-Yuan, S., 2010. Antimicrobial Susceptibility and Multiplex PCR Screening of AmpC Genes from Isolates of Enterobacter cloacae, Citrobacter freundii, and Serratia marcescens. J Microbiol Immunol Infect. 43(3):180-187.

60. Evans, B. A., Hamouda, A., Towner, K. J., \& Amyes, S. G. B. 2008. OXA-51-like $\beta$-lactamases and their association with particular epidemic lineages of Acinetobacter baumannii. Clinical microbiology and infection. 14(3): 268-275.doi: 10.1111/j.14690691.2007.01919.x.

61. Tadesse, E., Josephine, B., Daniel, A., Moses, N. N., Joyce, N., Wondwossen, A.G., John, S. G., Appolinaire, D., Ephrem, E.,2017. Genetic markers associated with resistance to beta-lactam and quinolone antimicrobials in non-typhoidal Salmonella isolates from humans and animals in central Ethiopia.Antimicrobial Resistance and Infection Control. 6:13. doi: 10.1186/s13756-0170171-6

62. Nashwa, M.A., Maysaa, E.Z., 2017. Molecular Study of Acinetobacter baumannii Isolates for Metallo- $\beta$-Lactamases and Extended-Spectrum- $\beta$-Lactamases Genes in Intensive Care Unit, Mansoura University Hospital, Egypt. International Journal of Microbiology. Article ID 3925868. doi.org/10.1155/2017/3925868

63. Chimanjita, P., Mangala, L., Swapnil, R., Kandarpa, K. S., 2016. Emergence of vanA gene among vancomycin-resistant enterococci in a tertiary care hospital of North - East India. Indian J Med Res. 143(3): 357-361. doi: 10.4103/0971-5916.182627 
64. D'Andrea, M. M., Nucleo, E., Luzzaro, F., Giani, T., Migliavacca, R., Vailati, F. \& Rossolini, G. M. 2006. CMY-16, a novel acquired AmpC-type $\beta$-lactamase of the CMY/LAT lineage in multifocal monophyletic isolates of Proteus mirabilis from northern Italy. Antimicrobialagents and chemotherapy. 50(2): 618-624. doi: 10.1128/AAC.50.2.618-624.

\section{Tables}

Table 1: primers used in the work-study. 


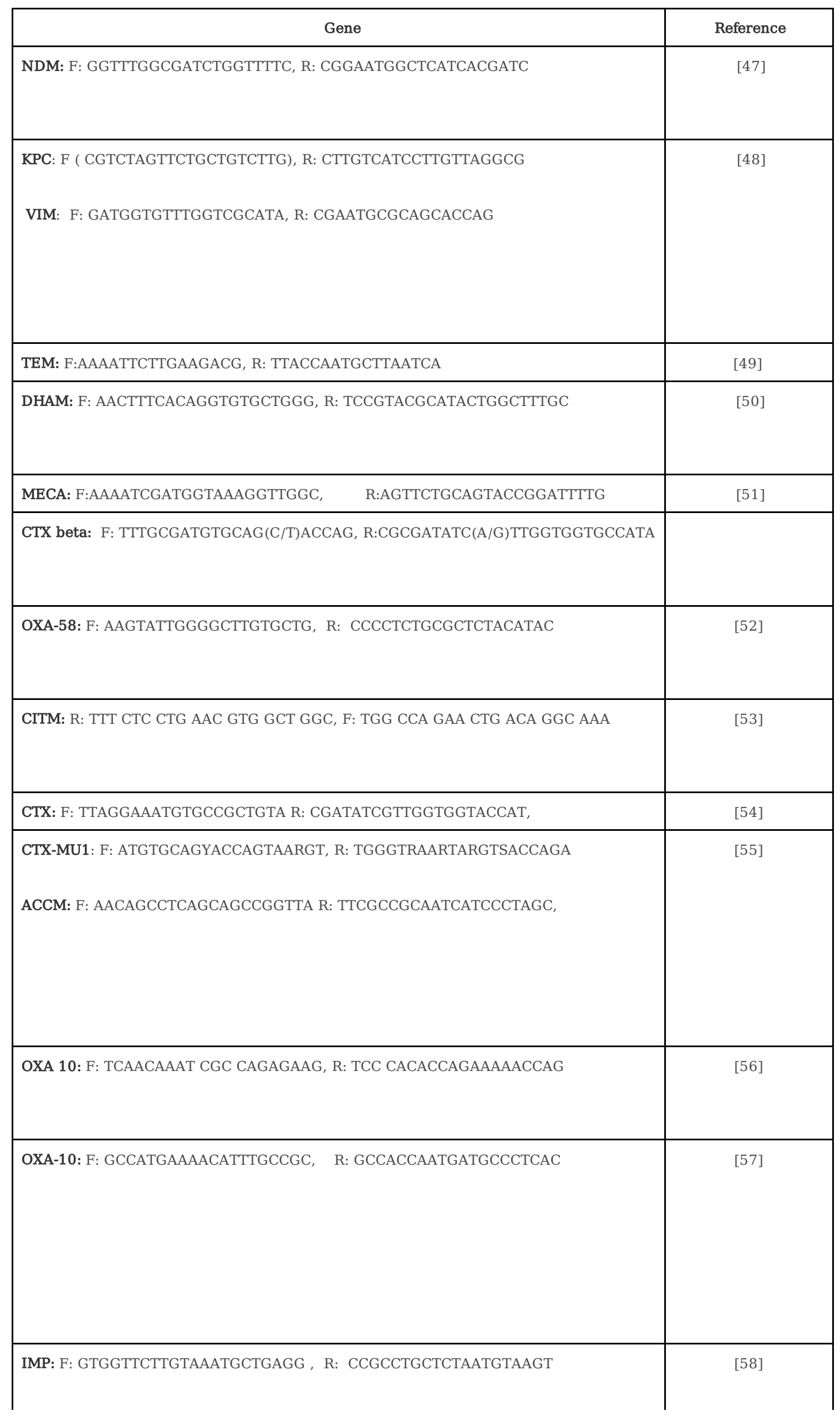




\begin{tabular}{|l|c|} 
& \\
\hline EBCM: F: TCGGTAAAGCCGATGTTGCGG, R:CTTCCACTGCGG CTG CCA GTT & {$[59]$} \\
\hline OXA-69: F: CTAATAATTGATCTACTCAAG R:CCAGTGGATGGATGGATAGATTATC, & {$[60]$} \\
\hline TOHO1: F: GCGACCTGGTTAACTACAATCC, R: CGGTAGTATTGCCCTTAAGCC & {$[61]$} \\
\hline BSHV: F:ATGCGTTATATTCGCCTGT, R:TGCTTTGTTATTCGGGCCAA & {$[62]$} \\
\hline VANA: F: GGGAAAACGCAA TTGC, R: GTACAATGCGGCCGTTA & \\
\hline FOX: F: CGAGCAGACSCTGTTCGAG R:TTGGCCAGCATGACGATG, & {$[63]$} \\
\hline
\end{tabular}

Table 2: Resistance prevalence of the bacterial isolates (30 isolate)

\begin{tabular}{|c|c|c|c|}
\hline Antibiotics & Resistance \% \% & Antibiotics & Resistance \% \% \\
\hline Colistin (CT) & 66.7 & Ceftazidime (CAZ) & 70 \\
\hline Ampicilin +Sulbactam (A/S & 90 & Amikacin (A/K) & 83.3 \\
\hline Penicilin(P) & 83.3 & Clindamycin (DA) & 76.7 \\
\hline Chloramphenicol(C) & 76.7 & Rifampine(RA) & 86.7 \\
\hline Ofloxacin (OFX) & 83.3 & Nitrofurantion (F) & 96.7 \\
\hline Levofloxacin(LEV) & 86.7 & Cefoperazone (CFP) & 83.3 \\
\hline Cefepime (CPM) & 93.3 & Azetreonum (ATM) & 83.3 \\
\hline Meropeneme (MEM) & 70.7 & Tetracycline (TE) & 80 \\
\hline Metronidazole (MTZ) & 100 & Streptomycine (S) & Trimethoprim-sulfamethoxaz (STX) \\
\hline Doxycycline (DO) & 83,3 & & \\
\hline
\end{tabular}

\section{Figures}




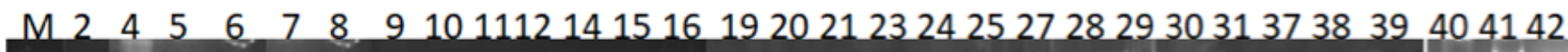

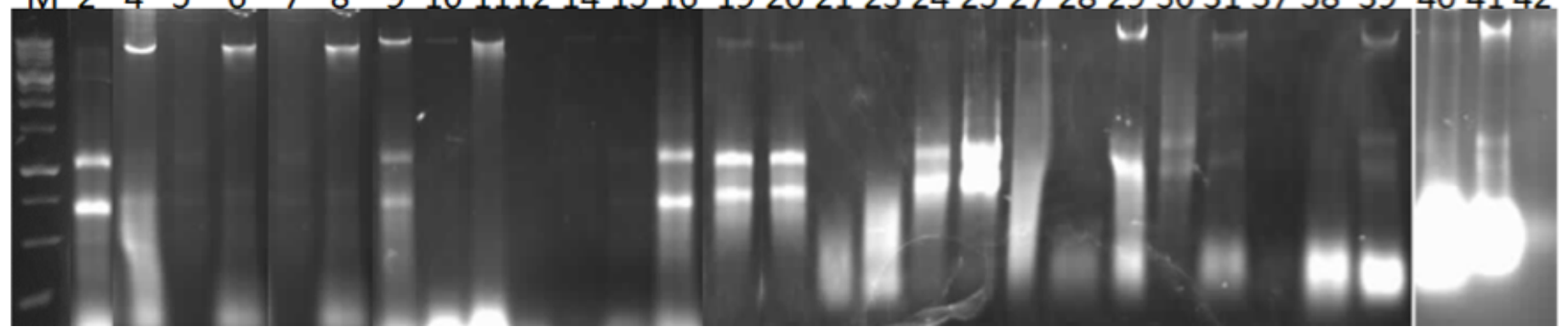

Figure 1

Agarose gel electrophoresis plasmid profiles of different bacterial isolates.

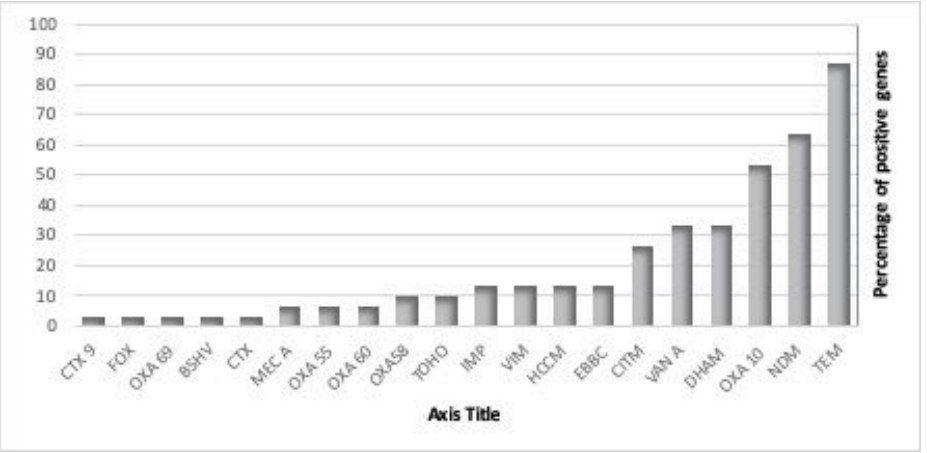

Figure 2

Average percentage of positive genes in all the selected MDR (30 isolates) 